\title{
Political Marketing: Exploring the Nexus between Theory and Practice in Ethiopia (Comparative Study between Ethiopian People's Revolutionary Democratic Front and Coalition for Unity and Democratic Party)
}

\author{
Mulugeta Girma \\ Department of Marketing Management, Dire Dawa University, Dire Dawa, Ethiopia \\ Email: eledanamulugeta@yahoo.com,mulugetad@hotmail.com
}

Received 29 December 2015; accepted 24 April 2016; published 27 April 2016

Copyright (C) 2016 by author and Scientific Research Publishing Inc.

This work is licensed under the Creative Commons Attribution International License (CC BY). http://creativecommons.org/licenses/by/4.0/ (c) (i)

\begin{abstract}
The main purpose of the study was to explore the Nexus between Theory and Practice of political marketing in Ethiopia by examining the perceptions of members of EPRDF and CUDP political party. A mixed approach with 248 and 304 usable samples were collected from top members of two political parties randomly and relevant data were gathered, presented and analyzed using descriptive and inferential statistical techniques. The findings revealed that there was no formal marketing practice used by both parties and no department responsible for establishment of political marketing mix elements rather they seldom undertook conventionally by simply stand for what they believe, or focused on persuading voters to agree with their preplan ideas and policies which were relating with the selling concept and product concept.
\end{abstract}

Keywords

Electorate Market, Ethiopia, Political Commitment, Political Marketing, Political Parties

\section{Introduction}

Ethiopia and most other African countries experience various political incidents starting from the feudal, social-

How to cite this paper: Girma, M. (2016) Political Marketing: Exploring the Nexus between Theory and Practice in Ethiopia (Comparative Study between Ethiopian People's Revolutionary Democratic Front and Coalition for Unity and Democratic Party). Open Journal of Business and Management, 4, 329-344. http://dx.doi.org/10.4236/ojbm.2016.42035 
ism to democratic system and all have to sell their idea or policy either by force to the electorates or in a free market which all can be included under the broad concept of political marketing. Political marketing is a growing phenomenon as political parties are applying marketing concepts and techniques to help and achieve their goals. It is currently argued that for major parties to win elections they need to apply political marketing and become market-oriented; understand the demands of the public, and design a "product" to suit for the electorates [1].

By recognizing the political marketing benefits, majority of developed and a few developing countries are successful in implementing and using the concept of political marketing [2] though in Ethiopia, still no formal study is conducted on how the concept of political marketing practiced and exemplifies the use to the political parties through identification of their perceived status by its electorates, employees, and partners relative to its competitors and market. Although the use of marketing enables ubiquitous to such an extent that it has become impossible areas [3] and enables to anticipate wishes of its constituencies, create offering that integrates and articulates needs of biggest possible number of electorates [4]. On this regard, this research explored the practice and nexus with theoretical concepts of political marketing by taking Ethiopian People's Revolutionary Democratic Front abbreviated as EPRDF, that established in early 1989 and became the ruling political coalition Party in Ethiopia consisting of four political parties namely the Oromo Peoples' Democratic Organization, the Amhara National Democratic Movement, the Southern Ethiopian People's Democratic Movement and the Tigrayan People's Liberation Front [5] and Coalition for Unity and Democracy often referred to as Kinijit as $2^{\text {nd }}$ case which was also a coalition of four political parties of Ethiopia that i.e., all Ethiopian Unity Party, United Ethiopian Democratic Party-Medhin Party and Rainbow Ethiopia which combined to compete for seats in the Ethiopian General Elections held on May 15, 2005 [6] as comparative study base and addressing of the following objectives:

- Exploring how political parties members and leaders aware and understand political marketing;

- Exploring how the political parties implement marketing mix;

- Identifying which marketing orientation is fit to Ethiopian political parties;

- Identifying how the political parties build position and manage image.

\section{Literature Review}

\subsection{Background}

Successful companies have a market orientation and are constantly engaged in creating value for their customers. In other words, marketers must anticipate their customers' needs, and then constantly develop innovative products and services to keep their customers satisfied [7]. And the same principles that operate in the commercial marketplace hold true in the political marketplace and are constantly trying to create value for their constituents by improving the quality of life, and creating the most benefit at the smallest cost [8] that leading to the concept of political marketing which is a very useful tool for a successful pre-election campaign, and although relatively new [9] and defined as the process of parties or candidates use opinion research and environmental analysis to produce and promote a competitive offering which will realize organization aim and satisfy groups of electorate in exchange for their votes [10], science of influencing behavior which includes set of strategies and tools to trace and study public opinion before and during an election campaign [11] and the outcome of the marriage between marketing and politics [12]. Also is concerned with communicating with party members, media and prospective sources of funding as well as the electorate [13]-[15].

Furthermore, it literally becomes impossible not to incorporate a marketing orientation when running for office, or for that matter, when running the country. Politics today is increasingly being influenced by marketing, which forced to rely on marketing not only to win the election, but also to be successful [16]-[35].

\subsection{Functions of Political Marketing}

Functions of political marketing are pre requisites for successful political marketing management. According to [10] [36]-[40], political marketing theorist, there are 8 generic functions starting from Product Function, which consists of three core components that are party image, leadership image and policy commitments and a mindset of voter-centredness [41] [42]. Distribution Function in politics consist two aspects; that are campaign delivery and offering delivery [12]. Cost Function: refers to the management of attitudinal and behavioral barriers of voters through calculated campaign strategies [43] Communication Function, consisting function of informing the primary exchange partner of the offer and its availability and it is often seen as the heart of political marketing 
[44]. News Management Function which is closely linked to communication function targeted to secondary exchange partners or intermediaries of which media is an important part [45]. Fund Raising Function consists of fund raising tasks to strengthen its capacity. Parallel Campaign Management Function describes co-coordinating campaign management activities of a political party with those of parallel organizations [46]. Internal Cohesion Management Functions, concerned with relationship with party members and activists as well as the spoke persons [47].

\subsection{Key Concept in Political Marketing}

Voter as a consumer: Marketers work very hard at shaping the expectations of their customers. Expectations of customers are often influenced by the gaps in thinking that exist between their own perceptions and those of the service provider. One gap exists between the expectation of the consumer and management's perceptions of those expectations. A second gap exists between quality specifications and service delivery. The third gap is between management perceptions and service quality specifications. Finally, gap can exist between the service delivery and external communications [48].

Anticipating voter needs: Success in marketing goes beyond the simple identification of the needs of consumers, but also includes the ability to forecast what those needs will be in the future. Marketers must not only be able to measure and identify the needs and wants of their customers', but they must also have a vision which enables them to anticipate what those needs will be. Whether it is a candidate, issue or product, marketing is a critical component to understanding what voters, citizens or consumers want and need. Needs may be driven by both emotion and rationality, resulting in people desiring the same product or candidate for different reasons [10] [49].

Marketing research in politics: Significance of doing research rests with the concept that not all products can be sold to all consumers. Companies use marketing research to determine what to stress to different consumer groups. Politicians are no different. Marketing research and polling are of course not new to the field of politics [50]-[65]. There are many different types of polls that candidates rely upon, including benchmark surveys (usually conducted after a candidate has decided to seek office to provide a baseline of information); trial heat surveys (used to group candidates together in hypothetical match-ups early in the campaign); tracking polls (conducted on a daily basis near election day to monitor any late shifts in support); cross-sectional and panel surveys (conducted by the major polling firms over time to provide a picture of where the electorate stands at different points during a campaign); and exit polls (carried out immediately after the voter casts his or her ballot) [66].

Market segmentation and targeting in politics: In business, market segmentation and targeting are used to identify those groups of customers who the marketer directs his product and promotional campaign towards [67]. It is used by many companies who choose not to sell their product or service to every potential customer, but only those who are likely to buy it. In politics, market segmentation has been traditionally used by each of the political parties to choose which segments of citizens they target with their appeals [67] [68].

Candidate positioning in politics: Once the multiple constituents segments have been identified, the candidate has to position himself in the electorate market. Positioning is multi-stage process that begins with the candidate assessing both his own and his opponents' strengths and weaknesses. Positioning is the vehicle which allows the candidate to convey his image to voters in the best light possible [18] [45] [69]-[78]. The image is crafted through the media by emphasizing certain personality traits of the candidate, as well as stressing various issues [79].

Image management: The image management process has also been used by political parties to manufacture "new and improved" images that more accurately align them with their changing constituencies. Along with this process has come a constant shifting back and forth of people from one party to another and a blurring of the definition of ideology in this country. In marketing terms, ideology is a "labeling" process, almost similar in nature to the use of branding for products. People have historically used ideology as a way of labeling both themselves and politicians, and then making a connection between themselves and the candidate and or political party through the use of this label. These labels are no different than the ones we see on products, as well as attached to services offered by a whole host of professionals who advertise in the hope of creating an image which defines who and what they stand for in the minds of consumers [71]. As a result of this change, ideology is now driven less by party affiliation and more by marketing, and the latest poll results indicting the mood of the electorate. Today, the labels liberal and conservative in politics are no longer defined by the political parties, but by 
the candidates themselves and the images their consultants craft for them. Along with this change has come a dramatic shift in power from the political party to the consultants [10] [80].

\subsection{Political Market Orientations}

There are three orientations; the first on is the Market-Oriented Party (MOP) which will use various tools to understand and then respond to voter demands, but in a way that integrates the need to attend to members' needs, ideas from politicians and experts and the realities of governing [81] [82]. A MOP party views and political judgment to design its behaviour to respond to and satisfy voter demands in a way that that meets their needs and wants, is supported and implemented by the internal organization, and is deliverable in government. Political marketing is used to understand the public, rather than manipulate it. Parties may use their ideology as a means to create effective solutions to public demands, but party elites try to respond to market demand, rather than trying to influence its opinion [83]. The second orientation is The Sales-Oriented Party (SOP) which aim to sell what they decide is best for the people, utilizing effective political marketing communication techniques. Market intelligence is used not to inform the product design, but to help the party persuade voters it is right [84].

Finally the Product-Oriented Party (POP) which is the most traditional approach to party behaviour and as such attracts less attention. A product-oriented party argues for what it stands for and believes in. It assumes that voters will realize that its ideas are the right ones and therefore vote for it. This type of party refuses to change its ideas or product even if it fails to gain electoral or membership support [85].

\section{Material and Methods}

\subsection{Description of the Study Area}

Ethiopia is found in the eastern part of Africa between latitudes of $3^{\circ}$ and $18^{\circ}$. and found in a favorable time zone for financial markets as it is situated at GMT+3:00, 8:00 Hrs. ahead of New York and 6:00 Hrs. behind Tokyo with capital city of Addis Ababa which center for many international organization including AU and called as the second Geneva of Switzerland [86]. Mean while following the failure of military junta lead by Mengistu H/Mariam, the country start to implement democracy which allow the right to form political party, participate in national and regional election [87] [88]. Currently more than sixty parties were found in the country; among this, CUDP and EPRDF was powerful in terms of competition which led in 2005 G.C. of Ethiopian election though it raises many controversies [89].

\subsection{Sampling, Data Collection and Analysis}

The study used descriptive research design because it enable to get a deeper understanding and rich explorations of the actual practice or application political marketing as it develops in a real-world setting and applied both quantitative and qualitative approach because, using both methods gain the best of both and increase its reliability [90]-[92]. And purposely takes Ethiopian people's democratic revolutionary front and collusion for unity party participated in 2005 and 2010 G.C. elections based on degree of acceptance and preliminary survey.

There were 61,763 Ethiopian people's democratic revolutionary front party members working on key areas of Addis Ababa city administrations [93] that were taken as a target population and determine the respondents using sample size determination formula from www.cengage.com/highered. Based on this, A total of 270 copies of printed questionnaire were distributed at EPRDF party session time randomly and collected only 248 of them. According to [94], sample size 30 - 500 is already adequate for most of the research [76]. For the CUDP that had 130,215 registered members; used Krejcie \& Morgan, tables to find a total samples of 368 at $95 \%$ confidence interval and collect 304 questionnaires.

The data were gathered personally using structured questionnaires developed based on literatures and face to face interview were also conducted with public relation office of respective parties. Data presentation and analysis of both parties were done using latest version of SPSS by applying descriptive and inferential statistical techniques supplemented with thematic analysis for interview section.

\section{Results and Discussion}

Gender is equally distributed across respondents. As shown in Table 1, most of the respondents are between 25 - 54 years old (84.7\%), with higher education (79.0\%) and, membership time of most of the respondents are 
Table 1. Summary of the Ethiopian people's revolutionary democratic front and Coalition for unity Democratic Party members characterstics.

\begin{tabular}{|c|c|c|c|c|c|}
\hline & & \multicolumn{2}{|c|}{ EPRDF } & \multicolumn{2}{|c|}{ CUDP } \\
\hline & & Frequency & Percent & Frequency & Percent \\
\hline & Male & 109 & 44.0 & 165 & 54.3 \\
\hline \multirow[t]{4}{*}{ Gender } & Female & 139 & 56.0 & 139 & 45.7 \\
\hline & Total & 248 & 100.0 & 304 & 100.0 \\
\hline & $18-24$ & 6 & 2.4 & 6 & 2.0 \\
\hline & $25-34$ & 53 & 21.4 & 109 & 35.9 \\
\hline \multirow[t]{6}{*}{ Age } & $35-44$ & 33 & 13.3 & 33 & 10.9 \\
\hline & $45-54$ & 124 & 50.0 & 124 & 40.8 \\
\hline & $\geq 55$ & 32 & 12.9 & 32 & 10.5 \\
\hline & Total & 248 & 100.0 & 304 & 100.0 \\
\hline & High school complete & 10 & 4.0 & 10 & 3.9 \\
\hline & Diploma & 42 & 16.9 & 50 & 14.7 \\
\hline \multirow[t]{6}{*}{ Educational background } & Degree & 160 & 64.5 & 198 & 67.9 \\
\hline & Second degree & 34 & 13.7 & 43 & 12.6 \\
\hline & Above second degree & 2 & 0.8 & 3 & 0.9 \\
\hline & Total & 248 & 100.0 & 304 & 100.0 \\
\hline & Above 15 years & 144 & 58.1 & 0 & 0.0 \\
\hline & $11-15$ years & 38 & 15.3 & 0 & 0.0 \\
\hline \multirow[t]{3}{*}{ Membership time } & $6-10$ years & 54 & 21.8 & 42 & 13.8 \\
\hline & 0 - 5 years & 12 & 4.8 & 262 & 86.2 \\
\hline & Total & 248 & 100.0 & 304 & 100.0 \\
\hline
\end{tabular}

Source: Survey Data, 2013/14.

between 6-above 15 years (95.2\%).

\subsection{Descriptive Analysis}

Every variable in the questionnaires were examined by several statements to investigate the variable were transformed into index by computing mean values of the responses in relation to political marketing concept practices. There were 43 items respondents could rate the practices of political marketing dimensions with theoretical perspectives. The average mean and mean values are presented in Table 2, together with standard deviation for each variables which defined as "the spread or variability of the sample distribution values from the mean" [95]. If the estimated standard deviation is large, response distribution values do not fall close to the mean of the distribution, the responses are inconsistent. On the other hand, if the estimated standard deviation is small, the response distributions are close to the mean, the responses are consistent [96]. 5-point Likert scale is employed.

High means express high agreement with the statements, while low means stand for lower agreement. Therefore in this comparative description of EPRDF and CUDP, the statements that describes Marketing application in politics has an average mean of $3.3095(\mathrm{SD}=0.7053)$, and $2.04115(\mathrm{SD}=0.48737)$ showing the application of marketing is rare and they simply give lip service for the concepts irrespective of the importance to bring considerable advantage. The dimensions that explain practice of Anticipating voter needs had average mean of 2.8537 (SD = 0.44066) and $3.0075(\mathrm{SD}=0.4905)$ respectively showing low values, meanwhile consideration of voters as a consumer were very low with average mean of $2.0726(\mathrm{SD}=0.49570)$ and $2.0148(\mathrm{SD}=0.4969)$ correspondingly; on the use of marketing research and market intelligence and its application in politics had average mean of $2.5282(\mathrm{SD}=0.5570)$ and $1.4803(\mathrm{SD}=0.5004)$ still low and, moreover the use, effectiveness, 
Table 2. Statistics indicating the application political marketing in Ethiopian people's revolutionary democratic front and Coalition for unity democratic party.

\begin{tabular}{|c|c|c|c|c|}
\hline \multirow[t]{2}{*}{ Dimension Used to Measure Practice of Political Marketing } & \multicolumn{2}{|c|}{ EPRDF } & \multicolumn{2}{|c|}{ CUDP } \\
\hline & Mean & Std. Dev. & Mean & Std. Dev. \\
\hline Marketing application in politics & 3.3095 & 0.70530 & 2.0411 & 0.48737 \\
\hline Requirement of marketing department for the party & 2.5887 & 1.0533 & 1.4803 & 0.50043 \\
\hline Giving lip service to the marketing concept. & 3.1855 & 0.88044 & 1.4803 & 0.50043 \\
\hline Determining customer needs work only business world & 3.7258 & 0.44701 & 3.7237 & 0.44791 \\
\hline Better plan vs. marketing strategy application & 3.7379 & 0.44066 & 1.4803 & 0.50043 \\
\hline Anticipating voter needs & 2.8537 & 0.70910 & 3.0075 & 0.49065 \\
\hline Party's devotion at determining voters 'needs and wants & 3.7339 & 0.44283 & 3.6184 & 0.48658 \\
\hline Party decisions should be voter oriented & 2.4355 & 1.0816 & 3.6184 & 0.48658 \\
\hline Conflicts on attempting to satisfy voter's needs and objectives. & 3.7177 & 0.45101 & 3.6184 & 0.48658 \\
\hline The notion of being oriented on satisfying voter needs too vague & 2.4315 & 1.0814 & 3.6184 & 0.48658 \\
\hline Political objectives overriding voter needs and wants & 3.7339 & 0.44283 & 1.4803 & 0.50043 \\
\hline Determining the needs and wants is a philosophy of the party & 2.3468 & 0.96114 & 3.6184 & 0.48658 \\
\hline Determining voter's needs increase political commitment & 1.5766 & 0.50321 & 1.4803 & 0.50043 \\
\hline The voter as a consumer & 2.0726 & 49570 & 2.0148 & 0.49679 \\
\hline Managing gap between consumer expectation and perceptions & 1.5726 & 0.49570 & 3.6184 & 0.48658 \\
\hline Managing gap on quality specifications and service delivery. & 1.5726 & 0.49570 & 1.4803 & 0.50043 \\
\hline Managing gap on perceptions and quality specifications. & 3.5726 & 0.49570 & 1.4803 & 0.50043 \\
\hline Managing gaps of service delivery and external communications. & 1.5726 & 0.49570 & 1.4803 & 0.50043 \\
\hline Marketing research and intelligence application in politics & 2.5282 & 0.5570 & 1.4803 & 0.52004 \\
\hline The party conducts market intelligence & 1.5726 & 0.49570 & 1.4803 & 0.50043 \\
\hline Surveying to find out what electoral services will need & 1.5726 & 0.49570 & 1.4803 & 0.50043 \\
\hline Survey to assess quality of policy and performance on post election & 3.3992 & 0.74061 & 1.4803 & 0.50043 \\
\hline Degree of responses to the research output & 3.5685 & 0.49628 & 1.4803 & 0.50043 \\
\hline Political communication & 3.0754 & 0.57870 & 2.7020 & 0.49250 \\
\hline The party understands the important of promotion & 3.5685 & 0.49628 & 3.6184 & 0.48658 \\
\hline The party has alternative promotional strategies & 3.5645 & 0.49682 & 3.6184 & 0.48658 \\
\hline The party is effective on implementation of strategies & 3.5524 & 0.49825 & 1.4803 & 0.50043 \\
\hline The party communication designed to persuade voters & 2.2863 & 1.06218 & 1.4803 & 0.50043 \\
\hline The party appear united and professional in the campaign to voters & 3.4879 & 0.50086 & 3.6184 & 0.48657 \\
\hline The party tends to eschew or avoid full-scale communication & 3.4960 & 0.50099 & 1.4803 & 0.50043 \\
\hline The party campaign is informed by market intelligence and targeted & 1.5726 & 0.49570 & 3.6184 & 0.48658 \\
\hline Market segmentation and targeting & 3.5802 & 0.49660 & 1.4803 & 0.50043 \\
\hline The party members Understanding the use of distribution & 3.5040 & 0.51690 & 1.4803 & 0.50043 \\
\hline The party member know Existence of segmentation strategy & 3.6184 & 0.48658 & 1.4803 & 0.50043 \\
\hline Implementation of segmentation strategies & 3.6184 & 0.48658 & 1.4803 & 0.50043 \\
\hline Candidate positioning and image management & 2.8166 & 0.49177 & 2.5493 & 0.49350 \\
\hline The party builds the overall party image & 2.5494 & 0.49351 & 3.6184 & 0.48658 \\
\hline
\end{tabular}


Continued

\begin{tabular}{|c|c|c|c|c|}
\hline The party build individual members image & 1.4803 & 0.50043 & 1.4803 & 0.50043 \\
\hline Manage the image, leadership image and policy & 3.6184 & 0.48658 & 1.4803 & 0.50043 \\
\hline Cascading of roles for members to represent party beliefs & 3.6184 & 0.48658 & 3.6184 & 0.48658 \\
\hline Reaction pattern & 1.5726 & 0.49570 & 2.193 & 0.40958 \\
\hline Competitors policy and tactical change takes the party forever & 1.5726 & 0.49570 & 3.6184 & 0.48658 \\
\hline Degree of response to competitors for any assault & 1.5726 & 0.49570 & 1.4803 & 0.50043 \\
\hline Degree of response for changes in competitor’s policy or direction & 1.5726 & 0.49570 & 1.4803 & 0.50043 \\
\hline Measurement and parameters & 2.2820 & 0.49520 & 1.4803 & 0.50043 \\
\hline The party has its own parameter to measure it over all performance & 3.0838 & 0.49004 & 1.4803 & 0.50043 \\
\hline Customer in the electorate market transact without incurring cost. & 3.4803 & 0.50043 & 1.4803 & 0.50043 \\
\hline Product development & 3.5352 & 0.49950 & 2.5493 & 0.49305 \\
\hline The party product designs have significantly done by the party itself & 3.5524 & 0.49825 & 1.4803 & 0.50043 \\
\hline The policy-design process show to include party views & 3.5161 & 0.50075 & 1.4803 & 0.50043 \\
\hline The party leader elected to suit the party & 3.5323 & 0.49997 & 3.6184 & 0.48658 \\
\hline Degree of believes on its product without consideration of publics & 3.5403 & 0.49938 & 3.6184 & 0.48658 \\
\hline
\end{tabular}

Source: Survey Data, 2013/14.

continuity of political communication had average mean value of 3.0754 (SD $=0.5787)$ and 2.7020 (SD = 0.4925) showing gaps in its practice. Furthermore the application of market segmentation and targeting has average mean value of $3.5802(\mathrm{SD}=0.4966)$ and $1.4803(\mathrm{SD}=0.50043)$ besides on the effort of Candidate positioning and image management, considering competitive reaction pattern, developing measurement and parameters, product design and development had average mean of 2.8166 ( $S D=0.0 .49177), 2.5493(\mathrm{SD}=0.0 .4935$ ), $1.5726(\mathrm{SD}=0.49570), 2.193(\mathrm{SD}=0.40958), 2.2820(\mathrm{SD}=0.0 .4952) 1.4803(\mathrm{SD}=0.50043), 3.5352(\mathrm{SD}=$ $0.4995)$ and $2.5493(\mathrm{SD}=0.49305)$ for EPRDF and CUDP respectively showing the existence of gaps on application of political marketing dimensions though there is crude justification on the benefit that could result in by using political marketing in their political practice.

where, $\mathrm{MP}=$ Marketing practice, $\mathrm{AVN}=$ Anticipating voter needs, $\mathrm{VC}=$ the voter as a consumer MRI $=$, Marketing research and market intelligence application in politics, $\mathrm{PC}=$ Political communication, MS = Market segmentation and targeting, CP IM = Candidate positioning and image management RP = Reaction pattern, and PD = Product development.

Table 3 shows except for anticipation of voters' need all the variables had value of greater than 0.5 for both CUPD and EPRDF confirming there is strong relationship between marketing application with effectiveness on considering voters as consumers and working to meet the demand with value of $0.727^{* *}$ and 0.643 respectively, application of marketing communication elements such as advertising publicities, direct and network marketing and others $\left(0.588^{* * *}\right.$ and 0.781$)$, the practice of market segmentation and targeting $\left(0.612^{* * *}\right.$ and $\left.0.541^{* *}\right)$, positioning and image management $\left(0.600^{* *}\right.$ and 0.711$)$ and keep eyes on competitors reaction pattern $\left(0.556^{* *}\right.$ and $0.737^{*}$ ) and striving to come up with new product or promising idea by striving on discovering unmet need of the electorates $\left(0.506^{*}\right.$ and $\left.0.651^{*}\right)$ with 0.00 significance level indicating a high statistical significance of the results.

Principal Factor Analysis (PFA) was conducted on 18 items used in the study (measured on a Likert 5-point scale; 1 = "strongly disagree to 5 = strongly agree"). The extraction method used was Principal Component Analysis with Varimax Rotation.

The Initial Eigen values-first 5 factors are meaningful as they have Eigen values $>1$ for EPRDF. Factors 1,23 , 4 and 5 explain 37.855\%, 14.021\%, 12.998\%, and 6.938\% (Table 4) of the variance respectively a cumulative total of 82.095\% (total acceptable) KMO score was 0.751 and Bartlett's Test of Sphericity 5985.002 (df = 153; p $=0.000$ ) though a loading of 0.722 considered as also significant (Stevens, 1992). For CUDP there were seven factors meaningful with a value greater than 0.1 and total acceptable value of $93 \%$. Whereas the Extraction 
Table 3. Correlation between marketing practices and application on Ethiopian people's revolutionary democratic front and Coalition for unity democratic party.

\begin{tabular}{|c|c|c|c|c|c|c|c|c|c|c|}
\hline & & MP & AVN & VC & MRI & P C & MS & CP IM & $\mathrm{RP}$ & $\mathrm{PD}$ \\
\hline \multirow{3}{*}{$\begin{array}{l}\text { MP for } \\
\text { CUDP }\end{array}$} & Pearson Correlation & 1 & $0.490^{* *}$ & $0.727^{* *}$ & $0.512^{* *}$ & $0.588^{* *}$ & $0.612^{* *}$ & $0.600^{* *}$ & $0.556^{* *}$ & $0.506^{*}$ \\
\hline & Sig. (2-tailed) & & 0.000 & 0.000 & 0.000 & 0.000 & 0.000 & 0.000 & 0.000 & 0.000 \\
\hline & $\mathrm{N}$ & 304 & 304 & 304 & 304 & 304 & 304 & 304 & 304 & 304 \\
\hline \multirow{3}{*}{$\begin{array}{l}\text { MP for } \\
\text { EPRDF }\end{array}$} & Pearson Correlation & 1 & 0.607 & 0.643 & 0.715 & 0.781 & $0.541^{* *}$ & 0.711 & $0.737^{*}$ & $0.651^{*}$ \\
\hline & Sig. (2-tailed) & 0.000 & 0.000 & 0.000 & 0.000 & 0.000 & 0.000 & 0.000 & 0.000 & 0.000 \\
\hline & $\mathrm{N}$ & 248 & 248 & 248 & 248 & 248 & 248 & 248 & 248 & 248 \\
\hline
\end{tabular}

Correlation is significant at the 0.01 level (2-tailed). Correlation is significant at the 0.05 level (2-tailed). Source: Survey Data, $2013 / 14$.

Sums of Squared Loadings which have the effect of optimizing the factor structure provides similar information by equalizing the relative importance of the five factors for EPRDF and seven factors for CUDP based only on the extracted factors. And as shown in the data set before rotation factor one accounted for considerably more variance; the remaining four (37.855\% compare to $14 \%, 12.998 \%, 10.283 \%$ and $6.938 \%$ respectively) however after rotation it account for only 29.307 of variance compared to $16.682 \%, 14 \%, 135 \%, 11.511 \%$ and $10.460 \%$ respectively this leads us to the conclusion that a five factor solution will probably be adequate for application of political marketing data in case of EPRDF however in case of CUDP seven of them were sufficient for its application.

\subsection{Qualitative Analysis}

Though both parties did not have any marketing department, the task of marketing such as promotion, campaign management delivery (offer delivery and campaign delivery), searching for member, need identification and fund raising is under taken by bureau of regional departments with the collaboration of communication bureau of the parties.

Currently, EPRDF has 5.2 million members throughout the country who live with the societies and playing; an intelligence role on identifications of the society's problem. Furthermore, in order to chalked out again BORD with collaboration of Kebeles leaders and elders peoples conduct public secession to deal with problems and follow the following procedures (Figure 1) to recognize needs of the electorates and potential electorates.

Although experiencing of such type of communication with the public's were helps to identify existing problems, but regarding to identifications of the electorates latent demand there are difficulties unless intensive surveying and intelligence task done.

On the segmentations of the electorates market, EPRDF applied demographic and geographic bases even if CUDP had no a clear segmentation line rather swing left to right. The major focused area of the EPRDF is rural dwellers because they cover $85 \%$ of the populations (Figure 2). However, according to Cui \& Choudry, such big segmentation is viewed as anti marketing because of not considering the customer as a unique individual but as standardized within the segments. In contrary to this, [96] argue that some organizations need to have larger segments and they refer to this as counter-segmentation so that they can be beneficiary over cost reduction.

The second segmentation is focused on urban dwellers by highly emphasising on poor dwellers specifically on women's and youths to achieve objectives through organizing them in to females (set) leagues and youth leagues. Bannon portray that: all markets are not similar in terms of their desired outcomes, motives and behaviors. Understanding of such special segment group who covers the larger population segment could play a great role in campaign management. Also it is clear that Market is not a mass of potential customers all with the same values, desires, aspirations and ability to be a customer for any given organizations and using of such segmentation in defined manner help the party over the acquisition and retaining of loyal customers in the electorates market.

To communicate their ideas, policies or directions, both parities used print Medias such as magazine, news paper, before the election campaign is began. However, during the campaign period the both uses TV, radio, sticker, pamphlet, hats and others that have the logo of the party even uses SMS to motivate the peoples to elect the party in addition to utilizing of public relation as means of penetrating the electorates market. 


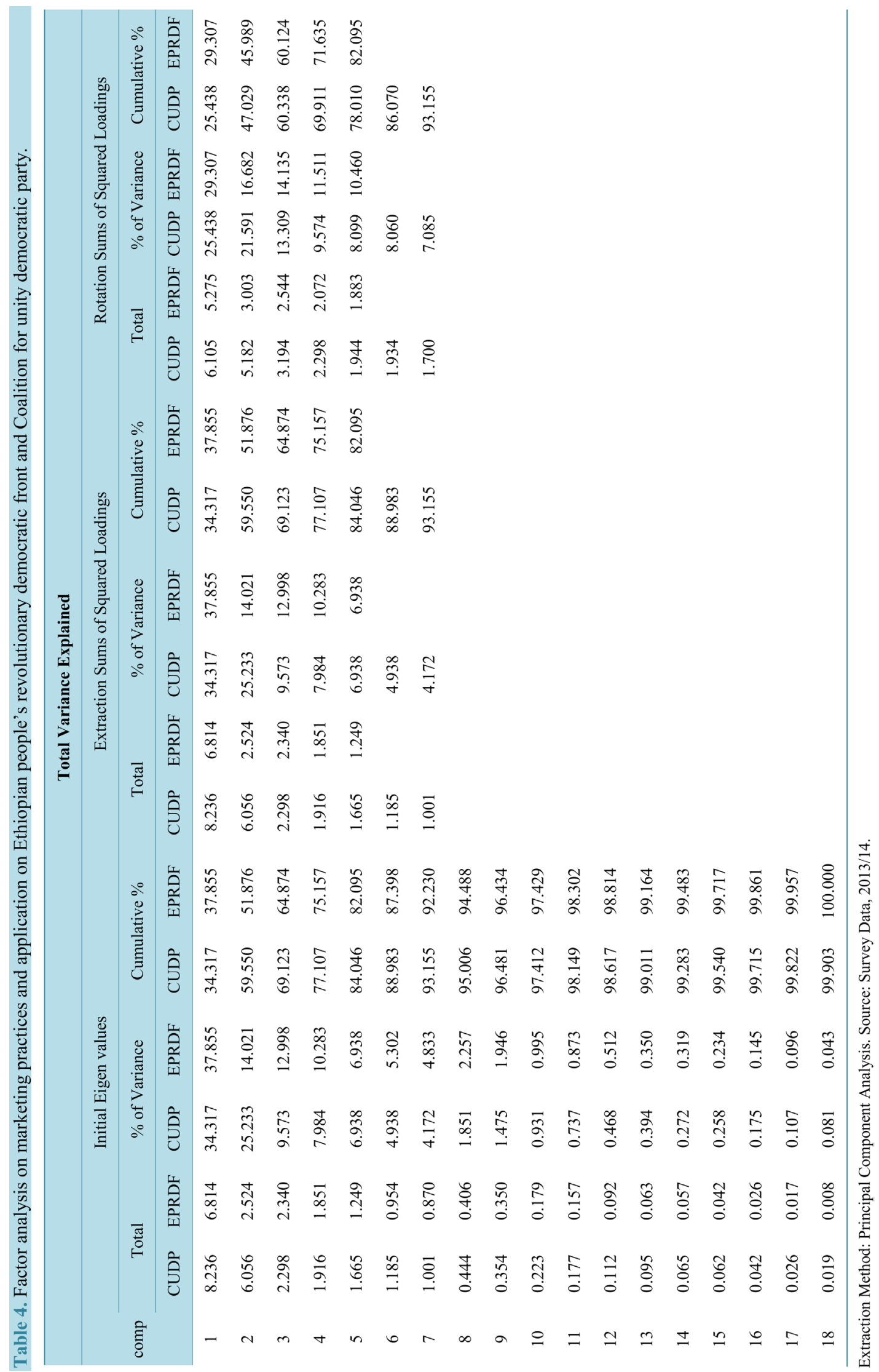




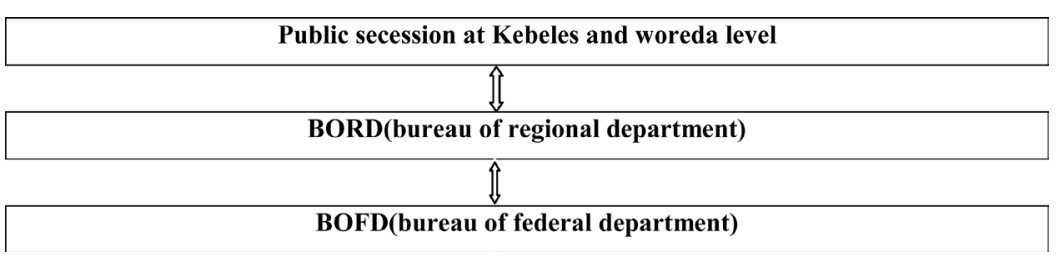

Figure 1. Process of need recognition in case of EPRDF source: Interview data 2013/14.

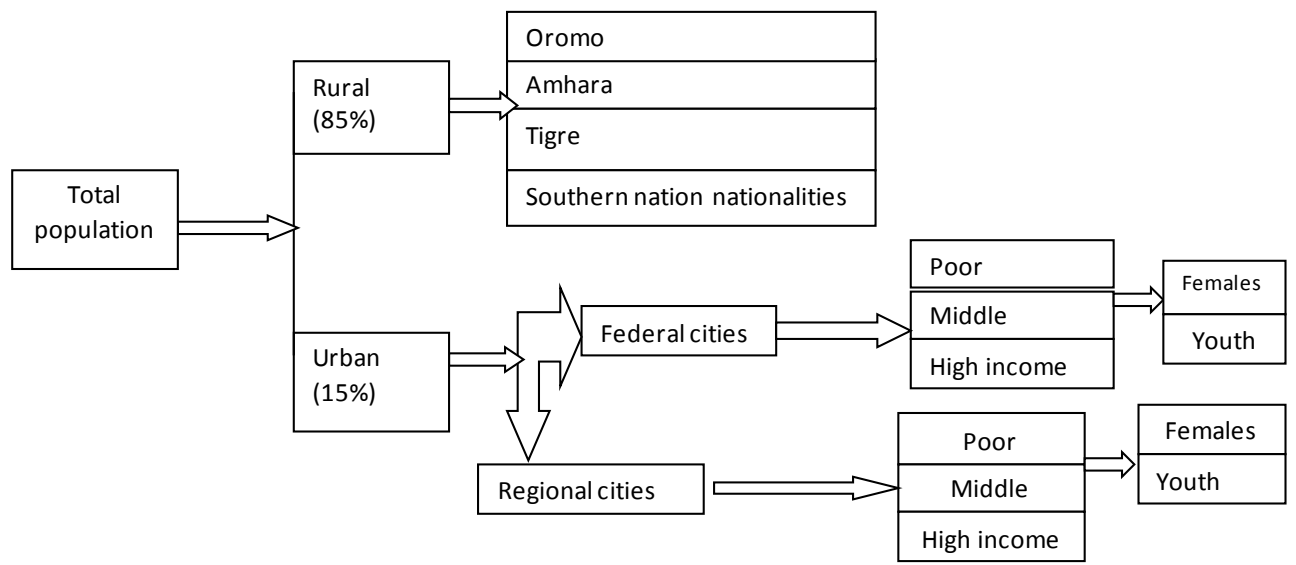

Figure 2. EPRDF segmentation Practices using geographic and demographic bases Sources: Interview data. 2013/14.

Though there is no clear parameters used to measure their act for CUDP, EPRDF employ dimension like following the principles of federalism, secularism, equality, unity and diversity, striving for national interest and considering poverty as the only enemy of Ethiopia in addition to parameters like focused on empowering females identification of the needy (child and disabilities), expansion of education to reduce illiteracy, increase accessibility health facilities, work on infrastructure development and believe on the principle of There is no permanent friendship in the absence of permanent benefit "are also the party philosophy". Finally EPRDF were not striving on building a single candidate name in the name of the party rather striving over building of overall image but not in case of CUDP that builds individual as well as organizational brand by endorsing special promotional strategies such as providing of well educated and famous persons as brand celebrities.

\section{Discussion and Recommendation}

\subsection{Discussion}

Political marketing is a very useful tool for a successful pre-election campaign, and although relatively new, it has been practiced in one form or another for some time [9]. Parties that aware of its true meaning should try to be more inclusive though there are challenges country like Ethiopia where it has fixed days and years on which the election undertaken, once the writ is dropped; there are normally only a few month in which to campaign before Election Days. This brief time period makes it difficult for new or unknown candidates to gain the visibility they need by practicing the marketing task unless they already have a high profile and form strong share of mind heart and market. Having this the following conclusions is extracted from the three analysis part of the study;

The average mean score for marketing application in politics which had four variables $=3.3095$ for EPRDF and 2.0411 for CUDP showing there is common understanding of marketing importance in politics by Ethiopian people's revolutionary party and a low understanding by collusion for unity party members. Whereas; on anticipating voter needs, that had seven variables, EPRDF score average mean of 2.8537 reflecting gaps on identifying and feeling voters need and become market orentidness including gaps devotion of member's party to feel demand of electorates. In contrary the average means score for CUDP was 3.1907 somewhat at positive level of anticipating needs though gaps are still there. 
On consideration of voter as a consumers that includes Managing gap between consumer expectation and perceptions, service delivery and external communications, perceptions and quality specifications, quality specifications and service delivery with mean value of 2.0726 shows the reluctant practice of EPRDF on recognizing electorates market customers that gives vote in exchange to the promising ideas or products. Mean while CUDP also score low average mean values (2.0148) existence of optimizing expectation through delivering quality service and communications. Furthermore, for the application of Marketing research and intelligence in politics which includes four variables, both parties has means sore of 2.5282 and 1.4803 showing low practice of research and intelligence services. And concerning to Political communication that have seven variables, have means score of 3.0754 for EPRDF showing there is understanding and application though gaps are still existed. Also CUDP score average mean of 2.0148 that reflect on low understanding application of marketing communication tools. Meanwhile, on Market segmentation and targeting understanding, application and consistency as well effectively, average means score $=3.5802$ and 1.4803 for both parties showing EPRDF has in a good position on application and usage of the concept but not CUDP

Finally on Candidate positioning and image management with mean score of 2.8166 showing gaps on practice of branding elements, reaction pattern with mean of 1.5726 Measurement and parameters with mean $=2.2820$ shows EPRDF has perform at low level in all area specially on the understanding and reflecting to the competitors was very low however on Product development and design the means score shows (3.5352) EPRDF has largely develop product without considering the need of the voters despite the interview part portray the party developing the product based on the need of the voters. Similarly CUDP also not considering what consumer really need or anticipation of need rather they develop their own product and force strive to convince the voters with the mean score of 2.3966. Generally, both parties have no conducting return on investment which identify the electorate market satisfaction or conduct research over the policy whether the electorates are satisfied or yet not happy and both parties give high emphasis to the internal politics compare to the external customers.

Also the correlation analysis shows there were high correlation between the application of promotion with winning election, segmentation with winning election, conducting research and having intelligence, understanding reaction pattern of competitor, considering voter as a consumer, and anticipating need and, product development at 0.00 significant level. Not only this for EPRDF the diagonal of anti image correlation matrix which show sample adequacy and KMO are all above 0.5 and the R square that indicate all represents the proportion of variance of each item explained by the factors except one (existence of marketing department within the party) have value of greater than 0.5. Furthermore, the study extracted five components for EPRDF seven for CUDP with the total Rotation Sums of Squared Loadings value of $82.095 \%$ and $93 \%$ respectively. The reliability statistics for both parties analysis have value of 0.872 for EPRDF and 0.983 for CUDP showing the study output is reliable and consistence.

\subsection{Conclusion}

In overall, EPRDF considers the heart beat of the voter despite the fact of failure to address what the electorate market need. They simply reflect what the party ideology seams, representing social movement during election time, unresponsive to social change because of many of the strategy developed by the top political leaders and appointees and implemented by other and finally they are striving for vote production and mass mobilization through campaigns. Although the party design product ideas accordingly based on internal policy, intra and party acceptability in addition to identifying voter demands to some extent and assessing deliverability of demanded policies even if it will have its own effect over the minority use communication medias and political intelligences, it is possible to categorize the party in between the product oriented type of party and market oriented party because of the party take elements both models [80]. Meanwhile the EPRDF implement segmentation. "Parties may simply stand for what they believe in, or focus on persuading voters to agree with them, or change their behavior to follow voters' opinions”. Having this, CUDP is striving over building of intra-organizational choice of policies, using of advertising and communication techniques to sell itself and get the power with a goal of persuasion in order to get the votes of the electorates, that makes them as sales oriented party despite the fact of failure to conduct research to understand what they need and want and having of thought of customers does not know what they need and want and to create a demand for the electorate which is against the marketing concept as well as the selling concept, believe and follow consumers are irrational at least as often as rational, motivated in large degree by emotions, habits and prejudices differing widely in personality structure, in 
aspirations, ideals and buying behaviors. Based on this the party fails between selling and market oriented model.

\subsection{Recommendation}

Peoples votes for peoples, not just party's sake or platforms; The more voters feel they have a personal connection to a particular candidates and parties, the more likely they give extra consideration especially if they are part of the ever-growing "undecided" category. Making that personal and political connection, however, is a challenge especially in Ethiopia where campaigns typically only last a few months from the writ calling for a vote to the actual Election Day and not actually having effective political marketing practice rather practicing selling concepts in their practice. To solve such issue for both federal and provincial candidates, they must work on branding, positioning and need intensively made campaign delivery and need to out from traditional practice of election and electorates cultivation that highly focusing on shading of black color and creating fear, anxiety by raising past history that specifically having black scare on certain ethnic groups. And need to effectively recognize what a promising idea do voters, need? How they want to serve by those groups and even they need to highly engaged in public relation works and cultivate public meeting culture to apply outside in approach and need to engage in philanthropic activities and should;

- Consult political marketing expertise or setup department that help to reach electorates market in a short period with limited budget and time by identifying the electorates need, want as well demand and be able to increase their chances of success or mentioning current positions.

- strive on understanding the principles of political marketing that helps parties to win consistently the heart and mind of electorates in order to survive in this new kind of electoral market, where voters act like consumers, parties act like businesses. Last but not list, knowingly or unknowingly for years politicians have relied on basic marketing skills-campaign buttons, posters, political rallies and campaign speeches to familiarize voters with a name, a party, and a platform that makes the use of marketing in politics is indispensible and understanding how it works and implanting it can help all parties regardless of their orientation in addition to its ability of supporting for the development of comprehensive voting system that make the citizen to feel included in each action.

\section{References}

[1] Lees-Marshment, J. (2001) The Product, Sales and Market-Oriented Party: How Labour Learnt to Market the Product, Not Just the Presentation. European Journal of Marketing, 35, 1074-1084.

http://dx.doi.org/10.1108/EUM0000000005959

[2] Scammell, M. (1999) Political Marketing: Lessons for Political Science. Political Studies, 47, 718-739. http://dx.doi.org/10.1111/1467-9248.00228

[3] Newman, B.I. (2002) Editorial: The Role of Marketing in Politics. Journal of Political Marketing, 1, 1-5. http://dx.doi.org/10.1300/J199v01n01_01

[4] Henneberg, S.C. (2005) Leading or Following? A Theoretical Analysis of Political Marketing Postures. Journal of Political Marketing, 5.

[5] Chanie, P. (2007) Clientelism and Ethiopia’s Post-1991 Decentralisation. Journal of Modern African Studies, 45, 355384. http://dx.doi.org/10.1017/S0022278X07002662

[6] Coalition's for Unity and Democracy Website (2009) Rights Watch Website Retrieved on 2008-07

[7] Kotler, P. and Levy, S. (1969) Broadening the Concept of Marketing. Journal of Marketing, 33, 10-15. http://dx.doi.org/10.2307/1248740

[8] Kotler, P. and Andreasen, A. (1991) Strategic Marketing for Non-Profit Organizations. 4th Edition, Prentice-Hall, Englewood Cliffs.

[9] Wring, D. (1996) Political Marketing and Party Development in Britain: A “Secret” History. European Journal of Marketing, 30, 100-111. http://dx.doi.org/10.1108/03090569610149818

[10] Lees-Marshment, J. (2009) Political Marketing Theory and Practice: A Reply to Ormrod's Critique of the LeesMarshment Market-Oriented Party Model. Politics, 26, 119-125. http://dx.doi.org/10.1111/j.1467-9256.2006.00258.x

[11] Kolovos, I. and Harris, P. (2005) Political Marketing and Political Communication: The Relationship Revisited. University of Otago, Dunedin.

[12] Lees-Marshment, J. (2001) The Marriage of Politics and Marketing. Political Studies, 49, 692-713. http://dx.doi.org/10.1111/1467-9248.00337 
[13] Lock, A. and Harris, P. (1996) Political Marketing-Vive La Difference. European Journal of Marketing, 30, $28-90$. http://dx.doi.org/10.1108/03090569610149764

[14] Kotler, P. and Kotler, N. (1981) Business Marketing for Political Candidates. Campaigns and Elections, 2, 24-33.

[15] Kotler, P. and Kotler, N. (1999) Political Marketing: Generating Effective Candidates, Campaigns, and Causes. In: Newman, B.I., Ed., Handbook of Political Marketing, Sage, Thousand Oaks, 3-18.

[16] Newman, B.I. (1981) The Prediction and Explanation of Actual Voting Behavior in a Presidential Primary Election. Unpublished Doctoral Dissertation, University of Illinois at Urbana-Champaign.

[17] Sabato, L. (1981) The Rise of Political Consultants: New Ways of Winning Elections. Basic Books, New York.

[18] Nimmo, D. and Rivers, W.L. (Eds.) (1981) Watching American Politics: Articles and Commentaries about Citizens, Politicians, and the News Media. Longman, New York.

[19] Altshuler, B.E. (1982) Keeping a Finger on the Public Pulse: Private Polling and Presidential Elections. Greenwood Press, Westport.

[20] Greenfield, J. (1982) The Real Campaign: How the Media Missed the Story of the 1980 Campaign. Summit Books, New York.

[21] Mauser, G. (1983) Political Marketing: An Approach to Campaign Strategy. Praeger, New York.

[22] Goldenberg, E.N. and Traugott, M.W. (1984) Campaigning for Congress. Congressional Quarterly Press, Washington DC.

[23] Alexander, H.E. (1984) Financing Politics: Money, Elections, and Political Reform. Congressional Quarterly Press, Washington DC.

[24] Graber, D.A. (Ed.) (1984) Media Power in Politics. Congressional Quarterly Press, Washington DC.

[25] Nieburg, H.L. (1984) Public Opinion: Tracking and Targeting. Praeger, New York.

[26] Polsby, N.W. and Wildavsky, A. (1984) Presidential Elections: Strategies of American Electoral Politics. Scribner, New York.

[27] Diamond, E. and Bates, S. (1984) The Spot: The Rise of Political Advertising on Television. MIT Press, Cambridge, MA.

[28] Newman, B.I. and Sheth, J.N. (1985) A Model of Primary Voter Behavior. Journal of Consumer Research, 12, 178-187. http://dx.doi.org/10.1086/208506

[29] Newman, B.I. and Sheth, J.N. (1985) Political Marketing: Readings and Annotated Bibliography. American Marketing Association, Chicago.

[30] Newman, B.I. and Sheth, J.N. (1987) A Theory of Political Choicen Behavior. Praeger, New York.

[31] Luntz, F. (1988) Candidates, Consultants, and Campaigns: The Style and Substance of American Electioneering. Blackwell, Oxford.

[32] Jamieson, K.H. (1992) Dirty Politics: Deception, Distraction, and Democracy. Oxford University Press, New York.

[33] Wring, D. (1999) The Marketing Colonization of Political Campaigning. In: Newman, B.I., Ed., Handbook of Political Marketing, Sage, Thousand Oaks, 41-54.

[34] Butler, P. and Collins, N. (1999) A Conceptual Framework for Political Marketing. Campaigning. Harvard International Journal of Press and Politics, 6, 31-43.

[35] Perloff, R.M. (1999) Elite, Popular, and Merchandised Politics: Historical Origins of Presidential Campaign Marketing. In: Newman, B.I., Ed., Handbook of Political Marketing, Sage, Thousand Oaks, 19-40.

[36] Wring, D. (1997) Reconciling Marketing with Political Science: Theories of Political Marketing. Proceedings of the 1997 Academy of Marketing Conference, Manchester, 1131-1144.

[37] Butler, P. and Collins, N. (1999) A Conceptual Framework for Political Marketing. In: Newman, B.I., Ed., Handbook of Political Marketing, Sage Publications, Thousand Oaks, 55-72.

[38] Henneberg, S.C.M. (2004) The Views of an Advocatus Dei: Political Marketing and Its Critics. Journal of Public Affairs, 4, 225-243. http://dx.doi.org/10.1002/pa.187

[39] Henneberg, S.C. and O’Shaughnessy, N. (2007) Theory and Concept Development in Political Marketing: Issues and an Agenda. Journal of Political Marketing, 6, 5-31. http://dx.doi.org/10.1300/J199v06n02_02

[40] Lees-Marshment, J. (2009) Political Marketing: Principles and Applications. Routledge, Abingdon, New York.

[41] Wring, D. (2005) The Politics of Marketing the Labour Party. Palgrave Macmillan, Basingstoke.

[42] O’Cass, A. (1996) Political Marketing and the Marketing Concept. European Journal of Marketing, 30, 37-53. http://dx.doi.org/10.1108/03090569610149782 
[43] Lees-Marshment, J. (2005) The Marketing Campaign: The British General Election of 2005. Journal of Marketing Management, 21, 1151-1160. http://dx.doi.org/10.1362/026725705775194148

[44] Newman, B. (1999) The Mass Marketing of Politics: Democracy in an Age of Manufactured Images. Sage Publications, Beverley Hills.

[45] Baines, P. (1999) Voter Segmentation and Candidate Positioning. In: Newman, B., Ed., Handbook of Political Marketing, Sage, Thousand Oaks, 403-422.

[46] Kavanagh, D. (1995) Election Campaigning: The New Marketing Politics. Blackwell Publishers, Oxford.

[47] Maarek, P. (1995) Political Marketing and Communication. Hohn Libbey, London.

[48] Niffenegger, P. (1989) Strategies for Success from the Political Marketers. Journal of Consumer Marketing, 6, 45-51. http://dx.doi.org/10.1108/EUM0000000002539

[49] Newman, B. (1994) The Marketing of the President: Political Marketing as Campaign Strategy. Sage, London.

[50] Newman, B.I. (Ed.) (1999) Handbook of Political Marketing. Sage Publications, Thousand Oaks.

[51] Lazarsfeld, P., Berelson, B. and Gaudet, H. (1948) The People’s Choice: How the Voter Makes up His Mind in a Presidential Campaign. Columbia University Press, New York.

[52] Eldersveld, S.J. (1951) Theory and Method in Voting Behavior Research. The Journal of Politics, 13, 70-87. http://dx.doi.org/10.2307/2126123

[53] Campbell, A. and Kahn, R.L. (1952) The People Elect a President. University of Michigan Survey Research Center, Ann Arbor.

[54] Berelson, B.R., Lazarsfeld, P.F. and Mcphee, W.N. (1954) Voting: A Study of Opinion Formation in a Presidential Campaign. University of Chicago Press, Chicago.

[55] Campbell, A., Gurin, D. and Miller, W.E. (1954) The Voter Decides. Row, Peterson, and Company, New York.

[56] De Sola Pool, I. and Abelson, R. (1961) The Simulmatics Project. Public Opinion Quarterly, 25, 167-183. http://dx.doi.org/10.1086/267012

[57] Tullock, G. (1967) Towards Mathematics of Politics. The University of Michigan Press, Ann Arbor.

[58] Macrae, D. (1970) Issues and Parties in Legislative Voting: Methods of Statistical Analysis. Harper \& Row, New York.

[59] Herndon, J.F. and Bernd, J.L. (Eds.) (1972) Mathematical Applications in Political Science. The University Press of Virginia, Charlottesville.

[60] Alker, H.R., Deutsch, K.W. and Stoetzel, A.H. (Eds.) (1973) Mathematical Approaches to Politics. Elsevier Scientific Publishing Co., New York.

[61] Markus, G.B. (1982) Political Attitudes during an Election Year: A Report on the 1980 NES Panel Study. American Political Science Review, 76, 538-560. http://dx.doi.org/10.2307/1963730

[62] Smith, T.W. (1982) House Effects and the Reproducibility of Survey Measurements: A Comparison of the 1980 GSS and the 1980 American National Election Study. Public Opinion Quarterly, 46, 54-68. http://dx.doi.org/10.1086/268699

[63] Bachman, J.G. and O’Malley, P.M. (1984) Yea-Saying, Nay-Saying, and Going to Extremes: Black-White Differences in Response Styles. Public Opinion Quarterly, 48, 491-509. http://dx.doi.org/10.1086/268845

[64] Mitofsky, W. (1998) Was 1996 a Worse Year for Polls than 1948? Public Opinion Quarterly, 62, $230-249$. http://dx.doi.org/10.1086/297842

[65] Mitchell, P. and Daves, R. (1999) Media Polls, Candidates, and Campaigns. In: Newman, B.I., Ed., Handbook of Political Marketing, Sage, Thousand Oaks, 177-196.

[66] Asher, H. (1998) Polling and the Public: What Every Citizen Should Know. 4th Edition, Congressional Quarterly Press, Washington DC.

[67] Newman, B.L. A Review in Political Marketing: Lessons from Recent Presidential Elections, DePaul University http://yaffecenter.org/downloads/Complete_List_of_Working_Papers/NEWMAN.pdf

[68] Johnson, R.M. (1971) Market Segmentation: A Strategic Management Tool. Journal of Marketing Research, 8, 13-18. http://www.jstor.org/stable/3149720 http://dx.doi.org/10.2307/3149720

[69] Patterson, T.E. (1980) The Mass Media Election: How Americans Choose Their President. Praeger, New York. In Newman's A Review in Political Marketing: Lessons from Recent Presidential Elections, DePaul University. http://yaffecenter.org/downloads/Complete_List_of_Working_Papers/NEWMAN.pdf

[70] Maddox, W.S. (1980) Candidate Images among Voters and Nonvoters in 1976. American Politics Quarterly, 8, 
209-220. In Newman’s A Review in Political Marketing: Lessons from Recent Presidential Elections, DePaul University. http://yaffecenter.org/downloads/Complete_List_of_Working_Papers/NEWMAN.pdf http://dx.doi.org/10.1177/1532673X8000800204

[71] Campbell, J.E. (1983) Candidate Image Evaluations: Influence and Rationalization in Presidential Primaries. American Politics Quarterly, 11, 293-314. In Newman's A Review in Political Marketing: Lessons from Recent Presidential Elections, DePaul University.

http://yaffecenter.org/downloads/Complete_List_of_Working_Papers/NEWMAN.pdf http://dx.doi.org/10.1177/004478083011003002

[72] Nimmo, D. (1970) The Political Persuaders: The Techniques of Modern Election Campaigns. Prentice-Hall, Englewood Cliffs. In Newman's A Review in Political Marketing: Lessons from Recent Presidential Elections, DePaul University. http://yaffecenter.org/downloads/Complete_List_of_Working_Papers/NEWMAN.pdf

[73] Nimmo, D. (1973) Images and Voters' Decision-Making Processes. Proceedings of the 4th Annual Conference of the Association for Consumer Research, 771-781.

[74] Elster, R.S. and Capra, J.R. (1972) Multidimensional Scaling of Political Preferences. Perceptual and Motor Skills, 35, 987-991. In Newman's A Review in Political Marketing: Lessons from Recent Presidential Elections, DePaul University. http://yaffecenter.org/downloads/Complete_List_of_Working_Papers/NEWMAN.pdf http://dx.doi.org/10.2466/pms.1972.35.3.987

[75] Wildman II, R.W. and Wildman, R.W. (1976) Note on Application of the Semantic Differential to the Electoral Process. Psychological Reports, 38, 1185-1186. In Newman’s A Review in Political Marketing: Lessons from Recent Presidential Elections, DePaul University.

http://yaffecenter.org/downloads/Complete_List_of_Working_Papers/NEWMAN.pdf http://dx.doi.org/10.2466/pr0.1976.38.3c.1185

[76] Mauser, G.A. (1980) Positioning Political Candidates: An Application Concept Evaluation Technique. Journal of the Market Research Society, 22, 181-191. In Newman's A Review in Political Marketing: Lessons from Recent Presidential Elections, DePaul University.

http://yaffecenter.org/downloads/Complete_List_of_Working_Papers/NEWMAN.pdf

[77] Goggin, M.L. (1984) The Ideological Content of Presidential Communications. American Politics Quarterly, 12, 361-384. In Newman’s A Review in Political Marketing: Lessons from Recent Presidential Elections, DePaul University. http://yaffecenter.org/downloads/Complete_List_of_Working_Papers/NEWMAN.pdf http://dx.doi.org/10.1177/1532673X8401200306

[78] West, D.M. (1984) Cheers and Jeers: Candidate Presentations and Audience Reactions in the 1980 Presidential Campaign. American Politics Quarterly, 12, 23-50. In Newman’s A Review in Political Marketing: Lessons from Recent Presidential Elections, DePaul University.

http://yaffecenter.org/downloads/Complete_List_of_Working_Papers/NEWMAN.pdf http://dx.doi.org/10.1177/1532673X8401200102

[79] Schweiger, G. and Adami, M. (1999) The Nonverbal Image of Politicians and Political Parties. In: Newman, B.I., Ed., Handbook of Political Marketing, Sage, Thousand Oaks, 347-364.

[80] Coleman, S. (2007) Review of Political Marketing: A Comparative Perspective. Parliamentary Affairs, 60, 180-186. http://dx.doi.org/10.1093/pa/gsl048

[81] Savigny, H. (2007) Focus Groups and Political Marketing: Science and Democracy as Axiomatic. British Journal of Politics \& International Relations, 9, 122-137. http://dx.doi.org/10.1111/j.1467-856x.2007.00253.x

[82] Lees-Marshment, J., Strömbäck, J. and Rudd, C. (Eds.) (2001) Global Political Marketing. Routledge, London, 23-28.

[83] Lees-Marshment, J., Strömbäck, J. and Rudd, C. (Eds.) (2001) Global Political Marketing. Routledge, London, 28.

[84] Lees-Marshment, J., Strömbäck, J. and Rudd, C. (Eds.) (2001) Global Political Marketing. Routledge, London, 28-31.

[85] Henze, P.B. (2000) Layers of Time: History of Ethiopia. C. Hurst \& Co. Publishers, London.

[86] Charter Center (2005) Final Statement on the Charter Center Observation of the Ethiopia 2005 National Elections. (September 2005): (unpublished).

[87] Pauswang, S., Kjetil, T. and Levies, A. (Eds.) (2002) Ethiopia since the Dergue. A Decade of Democratic and Pretension and Performance. Zed Books, London, New York.

[88] Ethiopian General Elections, 2005. http://www Wikipedia, free encyclopedia, 2005, accessed at may 2, 6:00 Am.

[89] Cassell, C. and Symon, G. (Eds.) (1994) Qualitative Methods in Organizational Research: A Practical Guide. Sage, London.

[90] Dawson, C. (2007) A Practical Guide to Research Methods, A User Friendly Manual for Mastering Research Techniques and Projects. 3rd Edition, How to Books Ltd., Oxfordshire. 
[91] Byrne, D. (2002) Interpreting Qualitative Data. Sage, London.

[92] EPRDF Party Manual That Shows Supporter and Member's Number, 2004 unpublished document of the party.

[93] Sekaran, U. (2009) Research Method for Business: A Skill Building Approach. 4th Edition, Wiley India, New Delhi, 464.

[94] Moloney, K. (2004) Is Political Marketing New Words or New Practice? UK PSA Conference. http://www.psa.ac.uk/journals/pdf/5/2004/Moloney.pdf

[95] Hair Jr., J.F., Money, H., Samouel, P. and Page, M. (2007) Research Methods for Business, California.

[96] Lees-Marshment, J., Strömbäck, J. and Rudd, C. (Eds.) (2001) Global Political Marketing. Routledge, London, 701. 